\title{
"SEEING" LIKE A SAGE: THREE TAKES ON IDENTITY AND PERCEPTION IN EARLY CHINA
}

For the early Chinese, sagehood represented something of a preoccupation. Since the fourth century BCE, few ancient thinkers have refrained from issuing pronouncements about sages-who sages were, what paths they took to achieve perfection, and even what they looked like. In addition, early Chinese thinkers also speculated about how sages "saw." They asked whether sages were endowed with extraordinary powers of sight and sound, they contemplated whether there were things that sages alone were able to detect, and they debated whether sages detected ruses.

Despite the importance of sagehood-and indeed, recent interest in the epistemology of the senses-scholars have paid scant attention to the issue of sagely perception. The topic, for example, is notably absent from Jane Geaney's important recent study, On the Epistemology of the Senses in Early China. ${ }^{1}$ Nor does it surface in important essays on epistemology in Chinese thought by Lisa Raphals, Christoph Harbsmeier, and David Keightley. ${ }^{2}$ Indeed, with the notable exception of Mark Csikszentmihalyi's brief discussion of the problem in his book, Material Virtue: Ethics and the Body in Early China, the subject has yet to occasion a full-length article or book. ${ }^{3}$

The omission is somewhat surprising since scholars have been aware of the linguistic connection between the term for sage (sheng 聖) and words for aural perception. As Ning Chen observes, sheng was cognate for “sound" (sheng 聲) and “to listen" (ting 聽). The fact that the sage was something of a perceptual "virtuoso" has moreover been duly noted. "[F]rom the perspective of ancient Chinese," Chen writes, "he who is keen in hearing is at the same time a wise man, able to distinguish between true and untrue." ${ }^{4}$ As Csikszentmihalyi similarly remarks, Warring States authors understood sagehood not as a "store of knowledge," or an ability to impart simple truths (as in ancient Greece), but as the "consequence of superhuman perceptions."

MIRANDA BROWN, Associate Professor, Department of Asian Languages and Cultures, University of Michigan. Specialties: Chinese history, history of science, Chinese philosophy. E-mail: mdbrown@umich.edu

UFFE BERGETON, Ph.D. student, Department of Asian Languages and Cultures, University of Michigan. Specialties: Chinese history, Chinese philosophy, linguistics. E-mail: bergeton@umich.edu 
In part, such an omission owes much to the presentation of sagely perception in works by Han thinkers. Through acts of omission and commission, they have played a contributing role in making the problem of how sages "see" seem either trivial or intellectually uninteresting. Classical commentators, for example, gloss over the problem. The cool-headed Zheng Xuan 鄭玄 (127-200), for example, notes simply, "Sages are perspicacious (tong 通) and possess foreknowledge (xianshi 先識)." ${ }^{\circ}$ Ying Shao 應邵 (fl. 186-200) offers a little more detail but nevertheless says little: "Sage: Sound, perspicacious. This is to say that the sage hears a sound and then knows the truth of matters; he penetrates all of Heaven and Earth and is clear about the myriad things." ${ }^{\text {" }}$ Such comments-which omit much detail and context-leave the impression that the issue was not a matter of either much controversy or interest. Even the prolix rants of Wang Chong 王充 (27-c.100), who was probably guilty of acts of commission, do not help matters. To be sure, the Lunheng 《論衡》 does leave tantalizing hints of a number of wild beliefs about sages, including marvelous powers of prophecy. And the text does adduce anecdotes about the extraordinary sensory acuity of the sages, which include the ability to "see through small apertures and perceive the minute." Nevertheless, Wang's straw-man presentation of contemporary beliefs - which he dismisses as the work of the benighted "literati" and "vulgar"-is suspect. ${ }^{8}$ Despite the richness of Wang's sources, such beliefs appear in the Lunheng as nothing more than specimens of illogic and superstition. In other words, they seem to be anything but the product of reasoned debate or serious theorizing.

What follows below is an attempt to rescue theories of sagely perceptiveness from scholarly oblivion. Before providing a road map to the arguments in this article, a few words about the sources to be examined are in order. To be sure, a comprehensive study of the problem is not feasible in the context of a single article; we thus restrict our discussion to three texts: the Xunzi《荀子》 (mid-third century вСE), Lüshi Chunqiu 《吕氏春秋》(239 все), and Huainanzi 《淮南子》(ca. 139 BCE). ${ }^{9}$ Naturally, questions may be raised as to why we focus on these texts in particular, rather than, say, the Zhuangzi 《莊子》or Xici《繫辭》. Our reasons for doing so, aside from considerations of space, are twofold. First, to give a sense of the sheer variety of contemporaneous views about sagely perception, we have chosen texts that can be dated firmly to within a century of each other. Unlike the Zhuangzi, the dates of these three texts are the subject of relatively little controversy. Second, comprehensiveness is a criterion. Certainly, other contemporaneous texts, such as the Han Feizi 《韓非子》(ca. $233 \mathrm{BCE})$, make references to sagely perception; yet the 
discussions of the problem found there is too limited to reconstruct a coherent theory of how sages "saw." Alternatively, the Zhuangzi says much about perception but refrains from producing a systematic account of what distinguishes the sage's particular way of perceiving from other kinds of men. The ideal perceptual agent in the Zhuangzi, such as Cook Ding, is never referred to explicitly as a sage or some other kind of perfected being, such as an "Arrived Man" (zhiren 至人) or "Perfected Man" (zhenren 真人). Similarly, while the Xici comments on the superior perceptive abilities of the sage, it does not provide much discussion of how sagely perception is different from that of other men. Thus, we include here only works that furnish sustained and explicit discussions of sagely perceptiveness.

In addition, a brief introduction to the words for perception that we will be using is in order. Early thinkers used a number of words for "perceiving." Many of these are related to the sense of vision or hearing, such as jian 見, “to see, perceive" and guan 觀 “to observe," shi 視 “to look at," ting 聽 “to listen to," and wen 聞 "to hear," etc. ${ }^{10}$ Other terms express mental forms of perception, and they include: cha 察 “to investigate, scrutinize," shen 審 “to examine," gan 感 “to be moved by, to feel," jue 覺 "to realize," etc. In addition, most verbs used for perception performed double-duty. Such words conveyed both the literal sense of using the eyes and ears to see and hear, as well as the more abstract sense of perceiving something with the mind, that is, knowing. A clear example of this is found in the received version of the Laozi《老子》, where it is said that the sage "does not look out his window but sees (jian) the Way of Heaven." Here, the sage is being praised for not perceiving the world through the eyes and ears; hence, the passage must have been referring to a more abstract sense of perception. ${ }^{11}$

This article falls into three parts, each of which examines how one text addressed the following questions: Who was the ultimate perceptual agent and what were the sources of sagely perceptiveness? We open by considering the question in relation to the Xunzi, which highlights the sage's unusual and unique perceptiveness with respect to the large pattern (dali 大理). As shown below, the differences between the sage and the rest reflected the former's clarified heart. We then turn to the Lüshi Chunqiu, which contrasts the sage's ability to discern human intentions from observation with the propensity of other men to be fooled. According to these authors, the sage's perceptiveness reflected his attunement to clues, which allowed him to tease out plots or see through ruses. We then turn to the Huainanzi, which asserts the sage's perceptiveness with respect to cosmological processes and human affairs. Quite paradoxically, the text argues that the unusual perceptiveness of the sage owed much to the fact that he 
refrained from using the senses. As such, the sage alone retained the means by which to perceive the Way. Consideration of the evidence thus reveals a more complicated picture of sagely perceptiveness than would be suggested by the presentation of Han thinkers. Indeed, the issue of how a sage "saw" represented a live problem in early Chinaone that the best minds of the third and second centuries BCE grappled with and to which they provided contrasting solutions.

\section{XUNZI}

Let us start with the Xunzi, asking what theories of sagely perceptiveness can be found there. Such a question is best answered by addressing several smaller issues: First, was in fact the sage the ultimate perceptual agent? Second, in what ways was the sage a better or ideal perceptual agent? As will be shown below, the sage is presented as the ideal perceptual agent in the Xunzi. What distinguished the sage from others was not sheer sensory acuity, but his unique insight into the patterns underlying human society.

The sage is represented in the Xunzi as being more perceptive about human affairs and the Way than other kinds of people. For example, we read that the sage "cannot be deceived" by false doctrines, whereas the multitudes can be "deceived about what they have seen with their own eyes." 12 The same idea is reiterated elsewhere, with slight variation: "[The sage] observes the disparate things and is not deluded." 13 Naturally, all this raises a question about whether perceptiveness is associated just with the sage-what about, for example, the gentleman (junzi 君子) or the well-born shi士? Here the text of the Xunzi, however, suggests that exceptional perceptiveness was a special attribute of the sage alone: "To conduct oneself in accordance with good models is the shi. To behave in ways that reflect steadfast earnestness is the gentleman. To be inexhaustible in one's all-encompassing clear-sightedness is the sage."14

Naturally, one might argue that the fact that the Xunzi associated sages with unusual perceptiveness requires little explanation. After all, was not sagehood synonymous with unusual perceptiveness or discernment, as mentioned above? Certainly, sages are associated with special perceptiveness in many early texts, notably, the Wuxingpian 五行篇, which was excavated from a fourth-century BCE site. ${ }^{15}$ Yet interestingly, early authors were not uniform in associating sages with special perceptiveness. The authors of the Zuo Zhuan 《左傳》, the Gongyang Zhuan 《公羊傳》, and Guliang Zhuan《穀梁傳》 did not explicitly do so. ${ }^{16}$ More tellingly, the Mencius (fourth to third century BCE) allows for the possibility that the sage could be a poten- 
tially poor judge of character; after all, the Duke of Zhou was betrayed by a treacherous brother. ${ }^{17}$

Perhaps then the emphasis on sagely perceptiveness can be explained as a rhetorical device? Some of the work may indeed have been intended for a royal or noble audience to win continued favor or even official employment. It was thus in the interest of the authors of the Xunzi to flatter the vanity of the ruler (who was most likely anything but sagacious). And this could be accomplished by speaking of the sage (sheng) as the ideal ruler, since sheng performed doubleduty in ancient China. Aside from being a term for a kind of cultivated person, it also was used as a part of an honorific address for people in court ("your sagacity"). By speaking of sages, the vanity of the ruler could be flattered by exploiting the ambiguity of the term while explaining how states ought to be governed. ${ }^{18}$

Not everything should be chalked up to rhetorical context, however. As will be demonstrated below, the Xunzi offers an elaborate account of the differences between what sages can perceive about the world and what can be perceived by others. Indeed, the elaborateness of the account leads us to suspect that there was a substantial theory behind assertions of the sage's unusual perceptiveness, one meriting further investigation.

What were the sources of the sage's unusual perceptiveness? One possibility, suggested by the work of the eminent historian of science, Steven Shapin, is that a distinction should be drawn between more or less competent perceptual agents. Whereas for some people the world of sight and sound was a reliable source of knowledge, others were incapable of perceiving "that which was available to be experienced, and thus reported upon." ${ }^{19}$ Certainly, a number of passages would suggest that such a distinction applied; consider the following anecdote:

South of Xiashou was a man there named Juan Shuliang. He was the kind of person that was foolish and easily frightened. There was a bright moon and he was walking in the night; looking down, he saw his shadow, mistaking it for a crouching ghost. Looking up, he saw his own hair, mistaking it for a standing devil. ${ }^{20}$

To be sure, the $X u n z i$ is not suggesting that the senses are misleading or systematically distorting "things as they are in themselves."21 According to Keightley, the text is calling attention to the propensity of people to misinterpret the information presented by their eyes and ears-that is, problems that occur in processing or identifying what is seen and heard. By Geaney's account, passages such as this illustrate how the authors of the Xunzi believed that certain influences contribute to sensory error or instances in which "sensory attention is misdirected." 22 
Certainly, the Xunzi acknowledges the possibility of sensory errors. There are indeed circumstances ( $s h i$ 勢) that makes it difficult for the senses to work properly. To cite an example from the Jiebi〈解蔽〉 chapter, if one walks in the dark, then a reclining stone will appear to be a crouching tiger, or a row of trees will appear like a group of men following behind. If the eyeballs are pressed, one will see one, instead of two, objects; likewise, by cupping the hands over the ears, one hears sharp dins as opposed to dull noises. ${ }^{23}$

Aside from extreme circumstances that make it difficult for a person to perceive the world correctly, the Xunzi also cites more systematic problems, including what we would call emotional or mental imbalance. Such imbalances were seen as leading to the senses being misdirected. ${ }^{24}$ Drunks, the text points out, will leap a chasm of a hundred paces because they mistake it for a half step. And this occurs because wine can disorder the spirit. Disordering the spirit, the Xunzi further notes, is no different from other actions that disable the senses. More seriously, having a heart that is unsettled will make it impossible for a person to determine clearly what he is seeing. In addition, suffering from muddled thoughts prevents a person from determining what does or does not exist. ${ }^{25}$ For this reason, people "deem that they see ghosts in the midst of confusion or at times when they are in doubt or are bewildered." 26

Although the Xunzi acknowledges that sensory errors were possible, such errors were not regarded as especially common or serious - a fact that suggests that most people were not seen as incompetent perceptual agents. Certainly, emotional imbalance or other circumstances could occasionally lead to mistaking a stone for a crouching tiger. But the text stops short of suggesting that people usually fail to make out objects. On the contrary, such sensory errors represent, as Geaney would put it, rare occurrences. ${ }^{27}$ To use an example from the $X u n z i$, if we look up at a forest from the top of a hill, the biggest trees appear no taller than chopsticks; yet because of the heart's oversight, no one mistakes trees for chopsticks, since they realize that the viewer's height obscures the actual size of the trees. ${ }^{28}$ Such discussions implicitly recognize that most people are competent perceptual agents - that is, they see and hear well enough to go about their daily affairs. To put it somewhat differently, one does not have to be a sage to realize that large trees appear small from distances.

To explain why the sage was more perceptive than other people, we must go beyond the dichotomy of competence and incompetence by asking why the sage represented a good, rather than merely competent, perceptual agent. As such, it is necessary to distinguish between objects of perception. As will be shown below, the Xunzi certainly distinguished between the ability to perceive mundane objects in the 
world, on the one hand, and the capacity for discerning the truth of matters or acquiring insight of underlying patterns ( $l i$ 理), on the other. Before going too much further, it is worth saying something about what the patterns were. Admittedly, the Xunzi is vague about this. Yet as Eric Hutton and others argue, the Xunzi uses the term to refer to a variety of things. On a smaller scale, the patterns entail mundane things in the world, such as the behavioral patterns of earthworms, and on a larger scale, they include cosmic patterns. On a still larger scale, the patterns-most often referred to as the "large" or "larger" patterns-refer to the Way, which the Xunzi interprets as providing a basis for human morality and social organization..$^{29}$ As we will see below, whereas most people had few problems perceiving mundane objects in the world and even potentially some cosmic processes, the Xunzi saw them as largely "blind with respect to the large pattern" or the Way (an yu dali 闇於大理).$^{30}$ Such blindness, we further learn, was the reason why his contemporaries followed the pernicious doctrines of the hundred persuaders, experts of statecraft, and other notable thinkers, including Mozi 墨子 (fifth to fourth century) and Mencius. ${ }^{31}$ In other words, such blindness explained why humans were confused about morality.

Let us begin with an obvious explanation of the sage's unusual perceptiveness. Perhaps the sage was more perceptive because he sees and hears literally better than others? Such an interpretation has its advantages. At the very least, it sits well with previous accounts of sagehood, which tend to depict sages as beings endowed with special aural skills or even extraordinary sensory acuity. ${ }^{32}$ In addition, this explanation would be consistent with the picture found in other early texts, including the Neiye〈內業〉 (fifth to fourth century BCE) chapter of the Guanzi《管子》, where self-cultivation and moral perfection are seen as leading to sharper faculties of sight and hearing, and ultimately, to comprehensive knowledge of the world..$^{33}$

Interestingly, the Xunzi offers little evidence that the sage is more perceptive about the world because he is endowed with special sensory acuity. To be sure, a few passages in the Xunzi link keen hearing and clear eyesight (congming 聰明) to sagely wisdom (sheng $z h i$ 聖知) ${ }^{34}$ Yet questions linger about whether such references are anything more than conventional metaphors. More problematically, the few passages in which the text comments upon the sage's eyes and ears suggest that he was not distinguished by any kind of special sensory acuity:

The eyes differentiate between white and black, and between the beautiful and the ugly. The ears differentiate between sound quality and pitch, and between clearness and muddiness; the mouth differentiates between the sour, salty, sweet, and bitter; the nose 
differentiates between the sweet smelling and fragrant and the putrid and foul. The skeleton, trunk, and the patterns of the skin differentiate between hot and cold, and between the painful and itchy. This is that which men are always born having, it is that which is not contingent on other things, and that in which the [sage] $\mathrm{Yu}$ and the [tyrant] Jie were alike. ${ }^{35}$

Admittedly, the passage does not rule out the possibility that the sage might see and hear better than others. That said, this is clearly not a point of emphasis. If anything, the text seems to be downplaying such differences in the interest of highlighting commonalities between all kinds of men. What is more, other passages state outright that heightened sensory acuity cannot be achieved through self-cultivation. In this connection, the Xunzi observes, "It is manifest that the clearsightedness of the eyes and the keenness of the ears cannot be [acquired] through study." 36

Instead, the Xunzi proposes that the sage's special perceptiveness owes much to the fact that his heart is in its ideal state. There, sages are defined as "numinous and fortified"; their hearts furthermore are said to be fully balanced and receptive to new impressions. ${ }^{37}$ Additionally, the sage is free from the "obscuration" or "blinding" of the heart, as he has "purified it and rectified his senses." 38

According to the Jiebi chapter, such perceptiveness allowed the sage to order the human realm more effectively because it gave him insight into cosmic patterns. As the text puts it: "When a person has achieved clarity and brightness, none of the forms of the myriad things are not visible; of those seen, none of them are not categorized (lun 論)." ${ }^{39}$ To be sure, being perceptive of the myriad things and cosmic patterns was not an end in itself. In Tianlun 〈天論〉, the authors insist, "Only the sage does not act to seek knowledge of Heaven." ${ }^{40}$ In other words, such perceptiveness is to be valued only where benefits to the social order can be obtained. This idea is reiterated elsewhere in the Jiebi chapter where the text stresses that the sage's perceptiveness of cosmic patterns makes him more effective at bringing order and prosperity to humans:

He observes distinctly the myriad things, thereby becoming aware of their characteristics, he deliberates and ascertains [the causes] behind order and chaos, thereby penetrating their system (? $)^{41}$; he gives order to heaven and earth, thereby discerning the characteristics and uses of the myriad things [i.e., for humans]; he cuts and divides the large pattern and thus the cosmos is fully ordered. ${ }^{42}$

What set sagely perception apart from that of ordinary humans, if anything? Interestingly, the sage was not presented as having particularly acute senses in the Xunzi. Although the author acknowledged the possibility of sensory errors and took care to explain their 
potential sources, the text stops short of suggesting that such errors prevented most people from acquiring knowledge about mundane aspects of the world. Instead, what distinguished the sage from most people was his power to distinguish true from false doctrines. Such a power, finally, owed everything to the sage's perceptiveness of normative patterns that underlay the human order. To put it somewhat differently, whereas the ordinary mortal was unable to grasp fully the essentials of human morality and social organization, the sage alone had insight into the Way because he possessed an unbiased, clarified heart.

\section{LÜSHI CHUNQIU}

We now turn to the Lüshi Chunqiu, asking of it the same questions raised earlier about the Xunzi-to wit, who was seen as the best perceptual agent? And how was such an agent different from others? As before, the sage is treated in the Lüshi Chunqiu as the best perceptual agent; sages alone could discern hidden schemes and underlying character through observation in situations where ordinary men would be fooled or remain in ignorance. Yet, the picture of sagely perceptiveness found in the Lüshi Chunqiu differs from that of the Xunzi on several counts. For a start, there is the question of what the sage was supposed to perceive (or better still, what sorts of things he alone was capable of perceiving). As we have seen in the Xunzi, the sage was distinguished by his ability to perceive underlying patterns. By contrast, foreknowledge of secret schemes and hidden intentions is highlighted in the Lüshi Chunqiu to a much greater extent. What is more, the authors provide a contrasting explanation of why sages perceive better. Whereas the Xunzi argued that the unusual perceptiveness of sages resulted from having a clarified heart, the Lüshi Chunqiu highlighted the sage's attunement to subtle details or external clues (wei 微 and biao 表).

At first glance, the Lüshi Chunqiu seems to offer little information about early Chinese attitudes toward sensory knowledge. Instead of discussing the reliability of the senses, the text focuses on the threat posed by the senses to the cohesiveness or health of the body. ${ }^{43}$ This does not mean, however, that epistemological concerns were absent from the text. On the contrary, we find a different kind of epistemological problem than the ones found in ancient Greece. More often than not, the major question in the Lüshi chunqiu was not whether the senses dissembled, but whether men and women did, and who could tell. Indeed, the problem of how observation could yield reliable information about other minds represents a significant theme there. 
Turning to the main subject of this article, let us ask who the best perceptual agent was supposed to be. Or to put it in the terms of the Lüshi Chunqiu: Was the sage the only one who could discern the truth of the human heart from observation? After all, it is one thing to argue that sages were apt interpreters of human behavior, but it is another to say that such an ability was attributed exclusively to sages. As it turns out, the evidence suggests the latter: Extraordinary clearsightedness, we will argue below, was associated only with sages in the Lüshi Chunqiu, rather than with other kinds of virtuous men, including worthies (xianzhe 賢者) or gentlemen.

More importantly, perceptiveness with respect to human intentions is treated as a litmus test of sagehood in at least one apocryphal anecdote concerning Lord Huan 桓 of Qi 齊 and his sagacious minister, Guan Zhong 管仲 (also known as Guanzi 管子, d. ca. 645 вCE). The pair had been plotting to attack the state of Ju 莒, but their plans became widely known before they could be carried out. Taken aback, Guan remarked, "There must be a sage in the state." Lord Huan thereupon guessed that the sage must have been one of the workers outside of the palace. The next day, the pair summoned the worker and asked him how he knew about the planned attack. The worker explained that the gentleman has three kinds of expressions. One was of pleasure, befitting someone listening to music; the second was of sorrow, appropriate for someone wearing the garments of mourning, and the last was of anger, of someone about to go to war. He then went on to explain how this related to his specific observations of the pair:

The other day, your servant had espied from afar your lordship on top of the terrace, abounding with rage. [The movement of] your lordship's hands and feet were restrained-the appearance of someone [about to go] to war. Your lordship opened his mouth but did not close it. Thus, that which he was saying was "Ju." Your lordship also raised his arm, pointing. What he faced was the state of Ju. Your servant secretly thought that the lord who had been disobedient could only be that of the state of Ju; thus he spoke of this matter. ${ }^{44}$

This anecdote reveals several points of interest. To begin, it confirms what Geoffrey Lloyd has argued. There was not as in ancient Greece an "ontological divide between the intelligible and the perceptible domains, or between being and becoming." Instead, it was possible to move down a "continuum" from the world of manifest phenomena, as Lloyd would put it, to the world of the hidden or formless through inferences drawn from observation. ${ }^{45}$ Yet the ability to perceive the hidden or formless-here, represented by secret plots-was not something everyone was thought to be capable of. Instead, as Guan Zhong's reactions reveal, it was unique to sages. As the text puts it in 
the concluding remarks about the episode, "The sage hears that which is without sound and sees that which is without form." ${ }^{\text {4 } 6}$

Having settled the issue of who the good perceptual agent was, we turn to our second question, namely, why sages were uniquely perceptive with respect to human affairs? Several possibilities, which will be examined below, present themselves: First, the sage's unusual perceptiveness was a reflection of his sensory acuity. A sage perceived things in a more complete way because he literally saw and heard better. A second possibility - which requires that we distinguish perceptiveness from simple sensory acuity-is that the sage was more perceptive because he was more discerning with his observations. He noticed details that other people ignored, or he was able to draw the right kinds of inferences from what was seen or heard by everyone.

Let us consider the first possibility, that is, the sage's unusual perceptiveness owed something to his extraordinary sensory acuity. Such an explanation is plausible, since some textual support can be found. In one place, the authors say that the sage "makes his spirit harmonized, his eyes clear-sighted, his ears keen, his nose sensitive, and his mouth nimble." ${ }^{47}$ The reason why the eyes and ears of sages surpassed those of others, the text explains, had to do with the fact that sages refrained from overusing them. ${ }^{48}$

Although sensory acuity was certainly one component that explained the sage's perceptiveness, it appears not to have been the only explanation provided by the Lüshi Chunqiu, nor the most important. As we will see below, the authors also explained the sage's unusual perceptiveness by his ability to notice clues that were ordinarily overlooked or misinterpreted by others. The authors highlighted two kinds of clues in particular: the subtle (wei) and external signs or cues (biao/zheng 徵). Often depicted as details easy to miss or behavior difficult to interpret, clues made the difference between a partial understanding of human affairs, on the one hand, and the infallible perceptiveness of the sage, on the other.

Let us start with the issue of subtle details, which are depicted by the authors as providing sages with foreknowledge of events to come. One passage, found in a chapter entitled "Scrutinizing the Subtle" (Cha Wei 察微), provides an illustration of this view:

If [the signs of] order and chaos and of survival and destruction were like the differences between the highest mountains and the deepest streams, if they were like the differences between white chalk and black paint, then there would be no place to use wisdom; instead, the foolish would be sufficient [for determining such things from signs].... Thus, the knowledgeable shi and worthies put together their thoughts and anxiously ponder in search [of such signs], and yet there was the affair of Guan and Cai [i.e., two royal uncles who rebelled against the Western Zhou king] and the disobedient plot of 
the Eastern Yi and the eight states. Indeed, the signs of order and chaos and of survival and destruction are in the beginning like autumn hairs. If one scrutinizes autumn hairs, then there will be nothing missed with respect to all under Heaven. ${ }^{49}$

Several points can be culled from the passage. Immediately, the political nature of the good perceptual agent's quest for knowledge is striking. At stake here is not whether he can know of future hurricanes or comets, but whether he can tease out the signs of imminent rebellions. Also worth pointing out is what might be called the authors' optimism: The roots of human disaster and fortune can always be known ahead of time so long as one is attentive to subtle signs of trouble. Yet interestingly, such optimism is offset by the awareness of the practical difficulties of noticing such signs, a point that is underscored by the comparison of the subtle to "autumn hairs." (On this point, the text recalls the Laozi, which describes the subtle as that which "one grasps but does not get." ${ }^{50}$ Catching the subtle is so difficult that the congresses of the knowledgeable or worthy are insufficient for discovering treacherous plots. This brings us to another point, namely, who can catch the "autumn hairs" or possess foreknowledge of human events. Although the authors do not say explicitly that the sage alone can know, this is strongly implied. As other passages in the Lüshi Chunqiu make clear, foreknowledge, or knowledge of "a thousand ages past and a thousand ages to come," is what sets the sage apart from other kinds of men. ${ }^{51}$

Naturally, the idea that foreknowledge was acquired by scrutinizing the subtle was not new or unique to the Lüshi Chunqiu. It can also be found in other third-century classics of statecraft, such as the Han Feizi. ${ }^{52}$ Some incarnation of the idea, moreover, had been in circulation for a long time. Certainly, there are hints of this view in the Laozi, where the author notes, "Seeing the small is what is called clearsighted." 53 There are also indications that such an idea derived from traditions of divination. For example, the Xici treats subtle or infinitesimal signs, including astrological omens, as carrying premonitions of the future. ${ }^{54}$ Interestingly, the Xici depicts subtle signs as being interpretable by gentlemen, as well as sages. ${ }^{55}$ Though less accomplished, gentlemen too could decipher clues. They "know of the minute and the obvious" (zhi wei zhi zhang 知微知彰) and can also “observe the traces" (guan xiang 觀象). ${ }^{56}$

What perhaps was new to the Lüshi Chunqiu was the emphasis on what the authors called external signs. This is the idea that sages have a complete understanding of other minds because they know how to discern the truths hidden behind things that were obvious to all. This view is exemplified in one chapter: 
The hearts of men are concealed and hard to see; profound, they are hard to fathom. Thus the sage scrutinizes the intentions [of others] through what they do. The way in which a sage surpasses other men is with his foreknowledge. To possess foreknowledge, one must scrutinize external signs and cues. Without external signs and cues to know things ahead of time, Yao and Shun [i.e., two ancient sage kings] would be no different from the multitudes. Clues vary and signs are hard [to grasp]; yet the sage is not flustered but the multitudes lack the means to grasp their meaning. ${ }^{57}$

It would be useful to draw out several relevant points. The authors open by suggesting that clues like external signs and cues can tip the observer off to the hidden thoughts of others. Such clues, however, are opaque; their meaning cannot be grasped through casual observation or by the multitudes (zhongren 眾人). In fact, the author emphasizes that the meaning of these clues can only be understood by sages.

Our foregoing discussion leaves us with the question of what counted as external signs? For the answer, we will have to turn to an anecdote, which reveals how signs, though visible to everyone, are properly perceived by very few. Once again, the machinations of Lord Huan and Guan Zhong take center stage. The pair had planned to attack Wei because the Wei emissary arrived late to a meeting of the overlords. When Lord Huan retreated to his private chambers, his consort (from Wei) went to the foot of the hall, begging forgiveness for her home state. Taken aback, Lord Huan protested that he had no business with Wei. The woman, however, retorted,

Your concubine espied from afar your lordship entering, with his stride high and his $q i$ abundant - a sign that he had the intention of attacking a state. When he saw his concubine, his appearance changed; this was a sign that he was going to attack the state of Wei.

The next day, the lord called over Guan Zhong, prompting Guan to ask him if he had abandoned his plans to attack Wei. Surprised, the lord then asked Guan how he knew this. "The way in which your lordship paid his salutations and held court," Guan replied, "was respectful and his manner of speaking was slow. When he saw his servant, he took on a shamefaced look, and this is how your servant knew of it." 58

To be sure, some readers will wonder whether the story is specifically about the sage's ability to grasp the meaning of manifest signs. In other words, how do we know that either Guan Zhong or the consort were sages? With respect to Guan, the answer is fairly obvious. Though Guan was sometimes depicted in unflattering ways in other texts, such as the Mencius, he is certainly presented as a sagely adviser 
throughout the Lüshi Chunqiu. ${ }^{59}$ Matters are more complicated in the case of the consort, who is otherwise a murky figure. In this connection, several points merit consideration. First, this anecdote appears in a chapter that illustrates specifically the sage's ability to grasp things through nonverbal or "subtle" communication (jingyu 精諭). Indeed, this woman is treated as belonging to the same category as Confucius. In addition, the anecdote fits the aforementioned description of the sage's interpretation of signs. Here, the sage's recognition of some sign affords her with knowledge of the hidden thoughts of others. In this case, the signs are none other than Lord Huan's pace, facial expression, and tone of voice. All of these things, of course, are far from invisible; nevertheless, they are decipherable only to the sage.

The authors of the Lüshi Chunqiu were optimists. In their view, the truth of matters - at least with respect to the thoughts and feelings of others - could be known through observation. In other words, the world of sight and sound did indeed represent a reliable source of information about people so long as the observer was attentive to subtle details, his senses acute, and his interpretation of manifest phenomena correct. Yet from another perspective, it may be argued that the authors of the Lüshi Chunqiu, like those of the Xunzi, were pessimistic about what could be known by most people. As with the Xunzi, the differences between what could be known by ordinary people, on the one hand, and by the sage, on the other, did not boil down to the ability to perceive mundane objects in the world. Rather, such differences had to do with the sorts of inferences about the world one could draw from what was seen or heard-in the case of the Lüshi Chunqiu, the sage was distinguished by his ability to detect human schemes and character from clues. Such clues allowed him to come to a complete understanding of human affairs and to glimpse the unfolding of events yet to come.

\section{HUANANZI}

We now turn to our final text, the Huainanzi. As will be shown presently, the good perceptual agent was none other than the sage (or, in some passages, an equivalent figure).$^{60}$ Sages there are not only exceptionally clear-sighted with respect to human affairs, but also extraordinarily perceptive about all things in the world, including the ineffable Way. That said, the picture of sagely perceptiveness found in the Huainanzi departs from the ones found in texts examined above. Whereas the Xunzi and Lüshi Chunqiu treat the eyes and ears as the source of knowledge about the world and even the Way, the Huainanzi $i$ argues something different. Sages perceive the world better than 
others because they shut down their senses and preserve their essence (jing 精) and spirit (shen 神), thereby intuiting the Way.

To address the first of our concerns (i.e., the identity of the good perceptual agent), the answer for the Huainanzi seems fairly straightforward. At least with respect to objects in the world, the sage or some equivalent figure is undeniably the best perceptual agent. As with the Lüshi Chunqiu, the sage is depicted throughout the Huainanzi as being uniquely clear-sighted, even prescient, with respect to human affairs: "Unless one is a numinous or sagely person, it is impossible to distinguish between [the signs of human fortune and disaster]." ${ }^{61}$ What is more, sages see through ruses, an ability that no doubt had its political applications. Comparing the sage's powers of discernment to the ability of legendary artisans to detect fakes, the authors assert that whereas the "muddle-headed ruler" would be led astray, sages alone are able to discern the character of "treacherous ministers, petty men, and false gentlemen." ${ }^{62}$ Additionally, the Huainanzi credits the sage with general perceptiveness: "Because [the sage's] essence and spirit are abundant, his $q i$ does not dissipate; and thus in hearing there is nothing he does not hear and in seeing there is nothing he does not see." ${ }^{63}$

Having shown that the sage was seen as the best perceptual agent in the text, we now turn to the more complicated problem-namely, how the authors accounted for the sage's unusual perceptiveness? As would be expected, some of the explanations found in earlier texts surface in the Huainanzi. One possibility, which recalls the discussion of the Xunzi, is that the sage's heart is free of disruptive influences, such as biases; hence, he is able to perceive the world as it is. Something like this is suggested below:

Knowledge is the store of the heart. When knowledge is universal, then the heart will be level. No one makes a mirror from running or turbid water; one makes mirrors instead from water that has stopped, because it is still. Likewise, no one examines one's form with crude iron; rather, one examines oneself in a polished mirror due to its evenness. Only when the heart is level and still can it reveal the nature of things. ${ }^{64}$

In addition to this explanation, there are indications that the authors of the Huainanzi thought that the sage's unusual perceptiveness reflected his attunement to clues. This explanation has its merits; at the very least, the authors of the Huainanzi comment repeatedly on how "only the sage is aware of the subtle" or how "the sage is cautious of the minute and mindful of the subtle." ${ }^{65}$ Yet aside from such comments, little else is said about the sage's attunement to the subtle or the importance of ridding the heart of biases, leading one to suspect 
that they were not the focus of the Huainanzi's discussion of sagely perceptiveness.

Sensory acuity - that is, being able to see and hear literally better than others-represents another possible source of the sage's unusual perceptiveness. ${ }^{66}$ Much is certainly made of sages having "ears and eyes that are clear, hearing and sight that is keen and sharp." ${ }^{67}$ Also, one passage hints that sensory acuity was connected to greater perceptiveness about the world:

If covetous desires are few, the eyes and ears will be clear, the sight and hearing sharp and keen. When the sight is sharp and the hearing is keen, this is what is called clear-sightedness ... ${ }^{68}$

Although this passage mentions sensory acuity in relation to selfcultivation, it is unclear whether it is the source of the sage's unusual perceptiveness about the world. Much depends on how the reference to “clear-sightedness" (ming 明) should be taken. Does "clearsightedness" here refer literally to being able to see well; or can it be understood more metaphorically, meaning to be discerning or intelligent?

Other evidence, however, suggests that sensory acuity is not the sole explanation. This is because the authors of the Huainanzi questioned whether the information from the senses could provide complete knowledge about the Way, which was regarded as being more than what could be seen and touched directly. Quoting the Laozi, they observed: "One can look at it [i.e., the Way] but not see its form, listen to it but not hear its sound, stroke it but fail to get it, and observe it but be unable to exhaust it." ${ }^{69}$ The same idea appears in other passages, where the authors play on the two senses of "clear-sightedness": "Those who employ their eyes and ears to see and hear tire their forms (i.e., their bodies) but are not clearsighted." 70

If sensory acuity was not behind the sage's extraordinary perceptiveness, what was? The answer to this question comes in the form of a familiar paradox: Sages and other perfected humans perceive the world better than other men because they do not use their eyes and ears to see-or, as the Laozi puts it, the sage is one who "does not look but is clear-sighted." ${ }^{\prime 1}$ For example, in one passage, the authors encourage men to follow sages in shutting down their eyes and ears: "Close up the nine apertures, seal the will and intentions, abandon the keenness and clear-sightedness [of the eyes and ears], and return to that-without-awareness." 72

Perhaps the injunctions to shut down the senses reflect a lack of consistency on the part of the authors? Certainly, the Huainanzi is an encyclopedic compilation-the work of multiple authors, who 
may have introduced potentially contradictory strands of thinking. Despite its composite structure, other studies have suggested that the Huainanzi can in fact be read as a coherent whole. ${ }^{73}$ Equally important, the text offers a solution to the apparent quandary. As seen below, its authors argue that the sage could preserve his essence and spirit and ultimately acquire superior powers of perception by shutting down the senses. The most explicit statement of this view is presented in a passage that elaborates on ideas found in the Laozi:

This is to say that when the essence and spirit dissipates to the outside [i.e., in the process of perceiving], the [faculties] of knowledge and reflection quake within and cannot fill up and order the form. As such, the spirit will be deployed far away, and what is left [i.e., the body] will be close. Thus [it is said of the sage], "One does not go outside one's door to know all under Heaven; one does not look through one's window to know the Way of Heaven. The further one goes, the less one knows." 74

Here, two themes come together: the need to refrain from sensory stimulation and the preservation of the essence and spirit. This, however, leaves us with the question of what was the connection between "knowing the conditions of all under Heaven," on the one hand, and refraining from sensory stimulation, on the other? For answers, we have to look elsewhere in the Huainanzi. To begin with, bear in mind that the authors thought, as Harold Roth has pointed out, that too much sensory stimulation could lead the essence and spirit to leave the body: "If [the essence and spirit] leaves the body for long and do not return, the form (i.e., the body) will close its internal openings, and the spirit will be without a way to enter." 75 Also worth noting is the fact that the authors regarded the spirit as the "source of knowledge" - and not any kind of knowledge, but knowledge of the ineffable Way ${ }^{76}$ As the authors put it, "Relying on the spirit residing in the efficacious repository [i.e., the heart], the sage thus returns to the beginning of things, observing where it is dark and listening where there is no sound." 77

As with the earlier texts surveyed above, the sage was the ultimate perceptual agent. Not only is the sage uniquely clear-sighted about human affairs, but he can also perceive the basic patterns of the cosmos. Yet there were also differences. Whereas the earlier texts would argue that the sage "sees" better because he makes more effective use of the information from his senses, the Huainanzi went so far as to question the value of sensory knowledge and conventional ways of apprehending the world altogether. Most strikingly, it stressed the importance of shutting down the senses to protect the spirit, the means by which one perceived the Way. 


\section{Conclusion}

In the pages above, we have made a first attempt to address a curious lacuna in the field - namely, the lack of substantive discussion about early Chinese theories of sagely perceptiveness. While our discussion does not pretend to be a comprehensive treatment of the subject, it nevertheless aims to reveal the extent to which the issue had captured the imagination of early Chinese thinkers. In addition, the issue of how sages "saw" represented something more than a general belief or cultural assumption, as the comments of Han thinkers or traditional etymology might suggest. On the contrary, early thinkers produced varied and diverging accounts of the sources of the sage's special perceptiveness. For the Xunzi, "seeing" like a sage meant ridding oneself of disruptive influences, thereby allowing the heart to register the information from the senses and to perceive the patterns underlying human society. For the Lüshi Chunqiu, it required special attunement to subtle details and telling clues, which enabled sages to pierce through the veil of appearance. For the Huainanzi, the sage's "seeing" necessitated shutting down the senses altogether and preserving the spirit in order to intuit the Way.

Our foregoing discussion leaves us with a question-namely, why did some thinkers choose not to join our authors in singling out the sage for his special perceptiveness? As we have noted above, the Zhuangzi highlighted the special perceptiveness of Cook Ding-but without sharply delineating the perceptive abilities of the sage from others. While this question lies outside the scope of this essay, we would like to venture a few preliminary thoughts in closing. One possibility is that such differences speak to the diverging agendas of the authors. Perhaps the focus on the sage's exclusive ability to perceive normative patterns reflected a larger defense of tradition within the Xunzi against its detractors? After all, the traditional rites and institutions enshrined the normative patterns of the sage. And if indeed the sage alone could perceive such patterns, we can see the necessity of preserving, rather than changing or rejecting, such traditions. Similarly, we may explain the interest in distinguishing sagely perception from that of ordinary mortals in terms of more basic emphasis on sagely exceptionalism in the Lüshi Chunqiu. Interestingly, the sages of the Lüshi Chunqiu seemed to have been born, not made. Such sages included children and illiterate field workers-in other words, individuals who were prodigies rather than the beneficiaries of extensive periods of ethical training. Finally, perhaps texts that refrained from elaborating on the differences between human and sagely perception see sages and ordinary mortals on a smoother continuum? To return to Wang Chong, might we see his denial that 
sages saw and heard better as part of a larger attack on sagely authority $?^{78}$ After all, Wang had noted that such beliefs about sages led his contemporaries to turn away from the testimony of their own eyes and ears. Complained Wang, "The age puts faith in empty and false documents, esteeming what they learn [literally: what they have heard] while denigrating what they see." ${ }^{.79}$ More problematically, such beliefs led to blind faith in old books, books that contained theories that contradicted common sense and personal experience: "They believe that those things put down to writing on bamboo and silk represent the traditions of the sages and worthies and thus contain nothing false." ${ }^{80}$ Admittedly, much more work will be necessary to bear out what we have only been able to allude to in brief. In order to understand why different thinkers articulated diverging positions on sagely perception, we will have to know more about the varied conceptions of sagehood more generally-in particular, who the sages were, whether they were born with exceptional qualities, and what characteristics qualified someone as a sage. That, however, is another article.

UNIVERSITY OF MICHIGAN Ann Arbor, Michigan

\section{ENDNOTES}

The authors would like to thank the anonymous reviewer, Bill Baxter, Professor Chungying Cheng, Eric Hutton, On-cho Ng, Michael Nylan, Henry Rosemont, and Yu Xie for their comments on this paper. In addition, we would like to dedicate this paper to Nathan Sivin. Research for this paper was conducted with the support of a faculty grant awarded to Brown from the National Endowment of the Humanities (Ref. FA 52204-06).

1. Jane Geaney, On the Epistemology of the Senses in Early Chinese Thought (Honolulu: University of Hawaii Press, 2002).

2. Lisa Raphals, "Skeptical Strategies in the Zhuangzi and Theatetus," in Essays on Skepticism, Relativism, and Ethics in the Zhuangzi, ed. Paul Kjellberg and Philip J. Ivanhoe (Albany: State University of New York Press, 1999), 26-49; Christoph Harbsmeier, "Conceptions of Knowledge in Ancient China," in Epistemological Issues in Classical Chinese Philosophy, ed. Hans Lenk and Paul Gregor (Albany: State University of New York Press, 1993), 11-30; David N. Keightley, "Epistemology in Cultural Context: Disguise and Deception in Early China and Early Greece," in Early China/Ancient Greece: Thinking through Comparisons, ed. Steven Shankman and Stephen Durrant (Albany: State University of New York Press, 2002), 119-53.

3. Mark Csikszentmihalyi, Material Virtue: Ethics and the Body in Early China (Leiden: Brill, 2004), 169-70, 174-75.

4. Ning Chen, "The Etymology of Sheng (Sage) and Its Confucian Conception in Early China," Journal of Chinese Philosophy 27, no. 4 (2000): 409-27, 414.

5. Csikszentmihalyi, Material Virtue, 170, 176.

6. Shisanjing Zhushu《十三經注疏》, ed. Zhouli Zhushu《周禮注疏》(Shanghai: Shangwu Yinshuguan, 1990), 10/159.

7. Ying Shao, Fengsu Tongyi Jiaozhu 《風俗通義校注》, annotated by Wang Liqi 王利器 (Beijing: Zhonghua Shuju, 1981), "Yiwen 佚文," 618. 
8. Huang Hui 黃暉, ed., Lunheng Jiaoshi《論衡校釋》, vol. 4 (Taibei: Shangwu Yinshuguan, 1969), 26/63.1063-79; esp. 1063-64, 1066, 1069.

9. See John Knoblock, Xunzi: A Translation and Study of the Complete Works, Volume I (Stanford: Stanford University Press, 1988), 28-105; Michael Loewe, "Hsün Tzu," in Early Chinese Texts: A Bibliographical Guide, ed. Michael Loewe (Berkeley: Society for the Study of Early China, 1993), 178-88; Michael Carson and Michael Loewe, "Lü Shih Ch'un Ch'iu," in Early Chinese Texts, 324-30; Charles Le Blanc, "Huai Nan Tzu," in Early Chinese Texts, 189-95.

10. For discussion of guan 觀, see Cheng Chung-ying, Yixue Benti Lun 《易學本體論》 (Beijing: Beijing University Press, 2006), 77-106; and Cheng Chung-ying, "On Human Consciousness in Classical Chinese Philosophy: Developing Onto-Hermeneutics of the Human Person," Journal of Chinese Philosophy 34, no. 1 (2007): 12-13, 16.

11. Gao Ming 高明, ed., Boshu Laozi Jiaozhu《帛書老子校注》(Beijing: Zhonghua shuju, 1996), 52-53; cf. Roel Sterckx, "Le pouvoir des sens: Sagesse et perception sensorielle en Chine ancienne," in Du Pouvoir. Cahier du Centre Marcel Granet I, ed. Rainier Lanselle (Paris: Presses Universitaires de France, 2003), 71-92; cf. 87-88; also see, Geaney, On the Epistemology, 36-40.

12. Xunzi Jijie, 6/81-82.

13. Ibid., $6 / 82$.

14. Ibid., 2/33; following Wang Niansun here in glossing $d u$ 篤 as $g u$ 固.

15. Jingmenshi Bowuguan 荊門市博物館, Guodian Chu Mu Zhujian《郭店楚墓竹簡》 (Beijing: Wenwu Chubanshe, 1998), “Wuxing 五行,” 150.

16. All this comes as less of a surprise when we consider that sagehood was de-emphasized throughout the corpus of the aforementioned Spring and Autumn traditions, where sheng occurs a scant 22 times throughout the corpus. Sages appear with somewhat greater frequency in the Sayings of the States (Guoyu《國語》); fifteen references to sages and nine to sage kings occur.

17. Jiao Xun 焦循, ed., Mengzi Zhengyi《孟子正義》, vol. 2 (Beijing: Zhonghua Shuju, 1987; reprinted 1991), 2B9: 293.

18. For examples of the ruler being addressed as a sage (shengzhu 聖主, shengshang 聖上) in Qin and Han times, see Sima Qian 司馬遷, Shiji 《史記》, vol. 10 (Beijing: Zhonghua Shuju, 1959; reprinted 1982), 80.2558; 101.2740; 101.2742, 110.2897; Ban Gu, Hanshu 《漢書》, vol. 12 (Beijing: Zhonghua Shuju, 1962; reprinted 1996), 25B.1259; 26.1311; 36.1970. For sheng as an honorific in Zhou bronze inscriptions, see Chen, "The Etymology of Sheng (Sage)," 414-15.

19. Steven Shapin, A Social History of Truth: Civility and Science in Seventeenth-Century England (Chicago: University of Chicago Press, 1994), 75.

20. Xunzi Jijie, 21/405.

21. Keightley, "Epistemology in Cultural Context,"133; Geaney, On the Epistemology, 33.

22. Geaney, On the Epistemology, 30-49; esp. 41.

23. Xunzi Jijie, 21/404-405.

24. Geaney, On the Epistemology, 36-37; 41.

25. Xunzi Jijie, 21/387.

26. Ibid., 21/404-5.

27. Geaney, On the Epistemology, 41.

28. Xunzi Jijie, 21/404.

29. Eric Hutton, "Moral Reasoning in Aristotle and Xunzi," Journal of Chinese Philosophy 29, no. 3 (2002): 355-84, 366-72; Aaron Stalnaker, "Rational Justification in Xunzi: On His Use of the Term Li," International Philosophy Quarterly 44, no. 1 (2004) 53-68; Chung-ying Cheng, "On Human Consciousness in Classical Chinese Philosophy: Developing Onto-Hermeneutics of the Human Person," Journal of Chinese Philosophy 35, no. 1 (2008): 9-31, 20-21.

30. Xunzi Jijie, $15 / 386$.

31. Ibid., 15/388-393.

32. Csikszentmihalyi, Material Virtue, 169-70; cf. David L. Hall and Roger T. Ames, Thinking through Confucius (Albany: State University of New York Press, 1987), 258, 363. 
33. See Li Xiangfeng 黎翔鳳, ed., Guanzi jiaozhu《管子校注》(Beijing: Zhonghua Shuju, 2004), 16/937, 939, 943. For discussion of the connection between self-cultivation and faculties of perception, see Harold Roth, "Psychology and Self-cultivation in Early Taoistic Thought," Harvard Journal of Asiatic Studies 51, no. 2 (1991): 599-650, esp. 614.

34. Xunzi Jijie, 6/99-100, 28/520.

35. Ibid., $4 / 63$.

36. Ibid., $23 / 436$.

37. Ibid., $8 / 133$.

38. Ibid., $17 / 310$.

39. Ibid., 21/397.

40. Ibid., 17.365; cf. Joseph Needham, Science and Civilization in China, Volume 2: History of Scientific Thought (Cambridge: Cambridge University Press, 1956), 26-29. For a revisionist view, see Michael J. Puett, Ambivalence of Creation: Cosmology, Sacrifice, and Self-Divinization in Early China (Cambridge: Harvard University Asia Center for the Harvard-Yenching Institute, 2002), 64-73.

41. The passage presents quite a few problems of interpretation. Here, we follow Wang Xianqian in glossing $d u$ 度 as $z h i$ 制 (system, regulations).

42. Xunzi Jijie, 21/397. Here we follow Wang Xianqian in glossing $l i$ 裹 as $l i$ 理 (to order, pattern).

43. Mark Edward Lewis, Construction of Space in Early China (Albany: State University of New York Press, 2006), 19-25; cf. Geaney, On the Epistemology, 20-21, 154-56.

44. Lüshi Chunqiu Jiaoshi, 18/1156-57. For similar tales, see Guanzi Jiaozhu 16/51.972; Wang Xianshen 王先慎, ed., Han Feizi jijie《韓非子集解》(Beijing: Zhonghua Shuju, 1998), 16/38.376-77.

45. Geoffrey Lloyd, "Appearances versus Reality: Greek and Chinese Comparisons and Contrasts," in Beiträge zur antiken Philosophie: Festschrift für Wolfgang Kullman, ed. Hans-Christian Günther and Antonios Rengakos (Stuttgart: F. Steiner, 1997), 303-17, 313.

46. Lüshi Chunqiu Jiaoshi, 18/1157.

47. Ibid., $1 / 20$.

48. Ibid., 1/21; cf. Boshu Laozi Jiaozhu, 12/273; Guo Qingfan 郭慶藩, ed., Zhuangzi Jijie 《莊子集釋》, vol. 4 (Beijing: Zhonghua Shuju, 1963, reprinted in 1993), 12/453;10/353.

49. Lüshi Chunqiu Jiaoshi, 16.6/1002-3.

50. Boshu Laozi Jiaozhu, 14/282.

51. Lüshi Chunqiu Jiaoshi, 11/604.

52. Han Feizi Jishi, 7/22.180.

53. Boshu Laozi Jiaozhu, 52/77.

54. Willard Peterson, "Making Connections: 'Commentary on the Attached Verbalizations' of the Book of Change," Harvard Journal of Asiatic Studies 42, no. 1 (1982): 94. For references to the original, see Shishan zhushu, ed., Zhouyi zhengyi 《周易正義》, “Xici shang〈繫辭上〉," (Shanghai: Shanghai Guji, 1990), 148,157, 172.

55. Peterson, "Making Connections," 94.

56. Zhouyi Zhengyi, "Xici shang," 173, 148. For a previous discussion of clues, see Marc Kalinowski, "La rhétorique oraculaire dans les chroniques anciennes de la China," in Divination et rationalité en Chine ancienne, Extrême-Orient, Extrême-Occident 21, ed. Karine Chemla, Donald Harper, and Marc Kalinowski (Paris: Centre national du livre, 1999), 37-65, 53-56. Also see in the same volume, Jean Levi, "Pratiques divinatoires, conjectures et critiques rationaliste," 67-77, 70-73.

57. Lüshi Chunqiu Jiaoshii, 20/1412-14. The passage presents a number of interpretative difficulties; at stake is how one translates $y i$ 易. Although other readings are possible, we are following Chen Qixian (20/1416 n. 10) here.

58. Ibid., $18.3 / 1168$.

59. See ibid., 24/1592-93. This chapter sets out to explain the importance of rulers "finding a sage" and includes Guan Zhong in their numbers.

60. For this issue, see Puett, To Become a God, 278-80. Puett has argued that the Huainanzi's "Lanming" 覽冥 chapter draws a sharp distinction between sages, individuals who have perfected their vision, and true men, who have "left behind the world of 
forms." Having examined all of the occurrences of shengren in the Huainanzi, we would argue, however, that the distinction between sages and true men is not as cut-and-dried as Puett suggests; our inclination would thus be to argue that the Huainanzi used shengren, zhiren, and zhenren interchangeably. All three of these represented perfected individuals who were distinct from the rest of humanity in terms of their perceptive and physical qualities.

61. He Ning 何寧, ed., Huainanzi Jishi《淮南子集釋》, vol. 3 (Beijing: Zhonghua Shuju, 1998), $18 / 1241$.

62. Ibid., 13/970-71.

63. Ibid., 7/511; cf. Wang Liqi 王利器, ed., Wenzi shuyi《文子疏義》(Beijing: Zhonghua Shuju, 2001) 3/116; cf. Puett, To Become a God, 278-80.

64. He, Huainanzi Jishi, 2/143. Following Wang Niansun 王念孫 and omitting $d u$ 睹. For a parallel passage, see Zhuangzi Jijie, 2B/193.

65. For example, see He, Huainanzi Jishi, 10/757; 18/1279; cf. Roth, "Psychology and Self-Cultivation," 632-63.

66. Griet Vankeerberghen, The Huainanzi and Liu An's Claim to Moral Authority (Albany: State University of New York Press, 2001), 111.

67. He, Huainanzi Jishi, 7/510; for a parallel passage, see Wenzi Shuyi, 3/116.

68. He, Huainanzi Jishi, 7/510; cf. Wenzi Shuyi, 3/116. The Wenzi passage explicitly mentions the sage as the subject.

69. He, Huainanzi Jishi, 2/95.

70. Ibid., 1/61; cf. Ibid., 2/86; Puett, To Become a God, 278-80.

71. Boshu Laozi Jiaozhu, 47/52-3.

72. He, Huainanzi Jishi $2 / 125$; cf. 7/526.

73. Vankeerberghen, The Huainanzi, 140-41.

74. He, Huainanzi Jishi, 12/893-94; cf. Wenzi Shuyi, 2/86; Han Feizi Jijie, 21/166-67.

75. He, Huainanzi Jishi 1/89; cf. D. C. Lau and Roger T. Ames, trans., Yuan Dao: Tracing Dao to Its Source (New York: Ballantine Books, 1998), 137. More work lies ahead in order to understand why sensory stimulation was thought to contribute to the loss of essence. One passage suggests that sensory stimulation caused the eyes and ears to intercept objects in space by releasing quantities of essence (jing 精).

76. He, Huainanzi Jishi, 2/143.

77. Ibid., 2/123; cf. Zhuangzi Jishi, 12/41.

78. Csikszentmihalyi, Material Virtue, 176.

79. Lunheng Jiaoshi, 18.56.813; cf. 26/79.1069.

80. Ibid., 4/16.157. 